\title{
Lipid metabolism in rats fed either butter or butter products as the fat source
}

\author{
By S. Labib, M. Sitohy, R. El-Massry and S. El-Saadany \\ Biochemistry Department, Faculty of Agriculture, Zagazig University, Egypt.
}

\section{RESUMEN}

\begin{abstract}
Metabolismo lipidico en ratas alimentadas con mantequilla o productos derivados de la mantequilla como fuente grasa.
\end{abstract}

Cuatro fuentes de grasas diferentes se administraron a ratas albino: aceite de maíz, mantequilla, "samn" y "morta" combinados con aceite de maíz. El grupo de ratas al que se le suministró mantequilla exhibió los índices más altos de colesterol, lípidos totales y triglicéridos en suero pero los más bajos de fosfolipidos, mostrando una tendencia similar los órganos corazón, hígado y bazo. Por otra parte, tanto las funciones hepáticas como renales de este grupo fueron dañadas. Los grupos de ratas a los que se les administró "samn" y "morta" se acercaron al control en la distribución de las fracciones lipídicas, tanto en suero como en órganos y mostraron débiles efectos sobre las funciones hepáticas y renales. - Rata.

PALABRAS-CLAVE: Alimento graso - Metabolismo lipidico

\section{SUMMARY}

Lipid metabolism in rats fed either butter or butter products as the fat source.

Albino rats were administered four different fat sources; corn oil, butter, samn and morta combined with corn oil. The butter rat group exhibited the highest rates of serum cholesterol, total lipids and triglycerides but the lowest one of phospholipid. The heart, liver and spleen organs of this group showed a similar trend. Both liver and renal functions of this group were impaired. Both samn and morta rat groups were close to the control in the distribution of lipid fractions either in serum or organs and showed slight effects on liver and renal functions.

KEY-WORDS: Fatty food - Lipid metabolism - Rat.

\section{INTRODUCTION}

Positive correlations have been observed between the consumption of food rich in cholesterol and mortality from coronary heart disease. High levels of blood cholesterol are regarded as a risk factor for cardiovascular disease, Nawar (1).
Butter was reported to have high content of cholesterol which might be a direct cause of elevated cholesterol levels in blood. Hence, cholesterol rich foods are regarded hygienically hazardous to many patients or healthy people.

Processing butter into samn was noticed to reduce the content of cholesterol and total sterols, Ismail and Hamed (2), Hassan et al. (3).

The purpose of this investigation is to biochemically trace the cholesterol in the products of heat treated butter; samn and morta compared to its content in the original butter. Albino rats were fed either butter, samn or morta supplemented with corn oil. Cholesterol was traced in blood serum and organs of the rats. Other related compounds and organ functions were also investigated.

\section{MATERIALS AND METHODS}

\subsection{Materials}

Buffalo butter was obtained from the local market. It was processed into samn and morta by heating for 2 hours and standing to cool at room temperature then separating the samn by decanting. Casein was purchased from Adwic Laboratory Chemicals, Cairo, Egypt. All the other diet ingredients and reagents were of analytical grade. Albino rats were obtained from the small animal unit, Faculty of Veterinary Medicine, Zagazig University.

\subsection{Experimental}

Sixty Albino rats, 60 days old weighing $90-110$ $\mathrm{g}$ were kept under ordinary healthy conditions and offerred the basal experimental diet after Campbell (4). The animals were divided into four groups which received the same mentioned diet but differred in the fat source. 
The first group diet contained $10 \%$ corn oil. The second and third groups diets received $10 \%$ of butter and samn respectively. The fourth group diet contained $10 \%$ of morta fat and corn oil. All the other diet ingredients were similar for the four rat groups. All groups received the diets ad libitum for total period of 4 months. After 2,3 and 4 months from the start of the treatment five rats of each group were killed by decapitation. Blood samples were collected and the organs; heart, liver, kidney and spleen were isolated and chilled until further analysis.

\section{Methods}

The methods of Knight et al. (5); Chaurchami et al. (6), Fletcher (7) and Bartlett (8) were applied for the determination of total lipids, total cholesterol, triglycerides and phospholipids in all the studied samples.

Serum glutamate oxaloacetate transaminase (GOT) and glutamate-pyruvate transaminase (GPT) were assayed according to Reitman and Frankel (9). Alkaline and acid phosphatases were determined according to Belfield and Goldberg (10). Total serum protein was analysed according to Lowry et al. (11). Uric acid and creatinine were determined according to Caraway (12) and Chasson et al. (13) respectively. Statistical analysis (t-test) was conducted according to Snedecor and Cochran (14). Serum Glucose was determined according to Tietz. (15).

\section{RESULTS AND DISCUSSION}

The data in Table I show the serum cholesterol content in Albino rats fed different fat sources. It is evident that the rats fed butter accumulated more cholesterol in their blood than those fed butter products; samn and morta or control. The maximum cholesterol levels were observed after three months of diet administration.

These results show that butter is comparatively the richest source of cholesterol while samn has lower content. The rat group fed morta combined with corn oil contained serum cholesterol values lower than butter and samn groups but still higher than control. This indicates that morta contained some low concentration of cholesterol which still gives rise to serum levels higher than control.

The reduced levels of cholesterol in butter products; samn and morta may be due to the oxidation of cholesterol during the severe heat processing of butter into samn. It is known that cholesterol can easily undergo autoxidation forming about 70-80 oxidation products (Smith (16); Nourooz-Zadeh and Appleqvist (17) and Park and Addis (18)). As cholesterol has an amphipathic nature, a considerable part of it might have aggregated with the protein components of morta either in its original or oxidized forms. Hence, it is clear that samn has lower content of cholesterol than butter as previously observed by Ismail and Hamed (2) and Hassan et al. (3). So, samn should be hygienically preferred to butter.

Table I

Changes in the serum levels of cholesterol, total lipids, triglyceride and phospholipids of rats administered different fat sources.

\begin{tabular}{|c|c|c|c|c|c|c|c|c|c|c|c|c|}
\hline \multirow[t]{3}{*}{ Treatments } & \multicolumn{3}{|c|}{$\begin{array}{l}\text { Total lipids } \\
\text { mg/di }\end{array}$} & \multicolumn{3}{|c|}{$\begin{array}{c}\text { Cholesterol } \\
\mathrm{mg} / \mathrm{dl}\end{array}$} & \multicolumn{3}{|c|}{$\begin{array}{l}\text { Phospholipids } \\
\text { mg/dl }\end{array}$} & \multicolumn{3}{|c|}{$\begin{array}{c}\text { Triglycerides } \\
\mathrm{mg} / \mathrm{dl}\end{array}$} \\
\hline & \multicolumn{12}{|c|}{ Time in months } \\
\hline & 2 & 3 & 4 & 2 & 3 & 4 & 2 & 3 & 4 & 2 & 3 & 4 \\
\hline \multirow[t]{2}{*}{ Control } & 466.4 & 482.5 & 564 & 126.8 & 128.6 & 142.5 & 135.6 & 138.6 & 146.5 & 50.2 & 56.4 & 62.4 \\
\hline & \pm 10.8 & \pm 39.4 & \pm 52.4 & \pm 10.5 & \pm 3.7 & \pm 13.4 & $\pm 11,6$ & \pm 12.4 & \pm 6.5 & \pm 4.31 & \pm 5.26 & \pm 3.62 \\
\hline \multirow[t]{2}{*}{ Butter } & 642.5 & 654 & $664^{*}$ & $152.6^{*}$ & $164.2^{*}$ & $185.6^{*}$ & $114.2^{*}$ & $118.5^{*}$ & $109.6^{*}$ & $72.7^{*}$ & $78.9^{*}$ & $84.9^{*}$ \\
\hline & \pm 61.4 & \pm 22.6 & \pm 20.4 & \pm 14.2 & \pm 15.4 & \pm 16.5 & \pm 11.2 & \pm 10.5 & \pm 8.4 & \pm 3.65 & \pm 2.94 & \pm 7.25 \\
\hline \multirow[t]{2}{*}{ Samn } & 525 & 564 & $597^{*}$ & 136.5 & $149.5^{*}$ & $156.2^{*}$ & 132.5 & 129.5 & $132.6^{*}$ & 58.6 & $59.6^{*}$ & $64.2^{*}$ \\
\hline & \pm 18.5 & \pm 42.6 & \pm 20.5 & \pm 12.6 & \pm 11.7 & \pm 13.8 & \pm 3.3 & \pm 11.9 & \pm 12.5 & \pm 2.05 & \pm 2.15 & \pm 5.6 \\
\hline Mớrta & 446 & 456 & $548^{*}$ & 129.5 & $146.3^{*}$ & $150.2^{*}$ & 145.6 & 156.5 & $162.8^{*}$ & 52.4 & $53.6^{*}$ & $59.6^{*}$ \\
\hline+ Corn oil & \pm 11.7 & \pm 25.7 & \pm 18.6 & \pm 8.5 & \pm 13.5 & \pm 14.5 & \pm 7.4 & \pm 6.5 & \pm 8.6 & \pm 4.3 & \pm 3.2 & \pm 5.4 \\
\hline
\end{tabular}

\pm Values it means standard deviation of the mean.

* Values are significant relative to control $(P<0.01)$ 
Simultaneously, the rat group receiving butter as the sole source of fat tended to contain higher serum levels of both total lipids and triglycerides than the control or morta group at the different experiment intervals. So, it can be concluded that the previously observed high serum cholesterol in butter rat group activated the transport of lipid components from the sites of absorption to blood circulation.

On the contrary the observed high levels of serum cholesterol in butter rat group were accompanied by lower phospholipid levels at the different experiment intervals compared to the other groups. So, it can be inferred that the higher levels of serum cholesterol have a negative effect on the biosynthesis of phospholipids. These relationship between serum cholesterol and serum phospholipid content were previously observed in the results of Mohamed et al. (19) and agrees with the finding of Abdel-Samad et al. (20) that cholesterol reduced the content of phospholipid in Saccharomyces carlsbergemesis.

The results in Tables II and III represent the accumulation of different lipid classes in the organs of rats fed different fat sources. It can be noticed that the organs heart, liver and spleen of the butter rat group retained higher levels of cholesterol than the other groups at the different experiment stages. So, it can be imagined that the rats with high serum cholesterol levels deposited or unloaded considerable amounts of their load of cholesterol in the organs which are in great contact with blood stream such as heart, liver and spleen. On the other hand both brain and kidney did not show any response to the high load of blood cholesterol.

Table II

Total lipids, triglycerides, phospholipids and cholesterol contents in heart and liver rats fed different butter products.

\begin{tabular}{|c|c|c|c|c|c|c|c|c|c|c|c|c|}
\hline \multirow{3}{*}{ Treatments } & \multicolumn{3}{|c|}{$\begin{array}{l}\text { Total lipids } \\
\mathrm{gm}^{\prime} 100 \mathrm{gm}\end{array}$} & \multicolumn{3}{|c|}{$\begin{array}{l}\text { Cholesterol } \\
\mathrm{mg} / 100 \mathrm{gm}\end{array}$} & \multicolumn{3}{|c|}{$\begin{array}{l}\text { Phospholipids } \\
\mathrm{mg} / 100 \mathrm{gm}\end{array}$} & \multicolumn{3}{|c|}{$\begin{array}{l}\text { Triglycerides } \\
\mathrm{gm} / 1 \infty \mathrm{gm}\end{array}$} \\
\hline & \multicolumn{12}{|c|}{ Time in months } \\
\hline & 2 & 3 & 4 & 2 & 3 & 4 & 2 & 3 & 4 & 2 & 3 & 4 \\
\hline \multirow[t]{2}{*}{ Control } & 1.35 & 1.46 & 1.56 & 134.5 & 140.5 & 154.6 & 320 & 316 & 334 & 1.08 & 1.12 & 1.23 \\
\hline & \pm 0.11 & \pm 0.12 & \pm 0.08 & \pm 12.5 & \pm 7.2 & \pm 9.5 & \pm 12.6 & \pm 30.2 & \pm 55.4 & \pm 0.09 & \pm 0.11 & \pm 0.12 \\
\hline \multirow[t]{2}{*}{ Butter } & 1.48 & 1.56 & 1.64 & $164.5^{*}$ & $173.2^{*}$ & $177.2^{*}$ & 310 & 315 & 316 & 1.13 & 1.26 & 1.14 \\
\hline & \pm 0.10 & \pm 0.13 & \pm 0.08 & \pm 10.5 & \pm 10.5 & \pm 13.5 & \pm 16.4 & \pm 29.5 & \pm 12.7 & \pm 0.07 & \pm 0.10 & \pm 0.08 \\
\hline \multirow[t]{2}{*}{ Samn } & 1.38 & 1.48 & 1.50 & 152.4 & 158.4 & 164.6 & 324 & 320 & 326 & 1.09 & 1.13 & 1.21 \\
\hline & \pm 0.09 & \pm 0.08 & \pm 0.08 & \pm 12.6 & \pm 13.5 & \pm 14.2 & \pm 31.4 & \pm 28.6 & \pm 20.5 & \pm 0.11 & \pm 0.12 & \pm 0.15 \\
\hline Morta + & 1.42 & 1.50 & 1.60 & 153.5 & 160.5 & 158.6 & 320 & 315 & 322 & 1.18 & 1.17 & 1.18 \\
\hline Corn ail & \pm 0.11 & \pm 0.12 & \pm 0.07 & \pm 14.3 & \pm 10.5 & \pm 7.5 & \pm 32.5 & \pm 30.2 & \pm 31.6 & \pm 0.12 & \pm 0.13 & \pm 0.12 \\
\hline \multirow[t]{2}{*}{ Control } & 4.63 & 4.96 & 5.62 & 248 & 25.5 & 274 & 325.6 & 332.7 & 342 & 4.23 & 4.54 & 4.84 \\
\hline & \pm 0.45 & \pm 0.04 & \pm 0.42 & \pm 13.5 & \pm 15.6 & \pm 22.1 & \pm 30.5 & \pm 16.4 & \pm 31.2 & \pm 0.34 & \pm 0.50 & \pm 0.42 \\
\hline \multirow[t]{2}{*}{ Butter } & $6.24^{*}$ & $6.34^{*}$ & $6.45^{*}$ & $425^{*}$ & $446^{*}$ & $468^{*}$ & 302.6 & 305.6 & 312.6 & 5.22 & 5.32 & 5.42 \\
\hline & \pm 0.52 & \pm 0.42 & \pm 0.34 & \pm 16.4 & \pm 19.5 & \pm 45.2 & \pm 18.6 & \pm 15.4 & \pm 12.4 & \pm 0.32 & \pm 0.50 & \pm 0.46 \\
\hline \multirow[t]{2}{*}{ Samn } & 5.84 & 6.21 & 6.24 & $305^{*}$ & $308^{*}$ & $320^{*}$ & 298.4 & 304.5 & 308.4 & 4.85 & 4.99 & 5.12 \\
\hline & \pm 0.13 & \pm 0.14 & \pm 0.52 & \pm 12.4 & \pm 11.4 & \pm 10.5 & \pm 29.4 & \pm 20.5 & \pm 18.4 & \pm 0.34 & \pm 0.41 & \pm 0.30 \\
\hline Morta + & 4.64 & 4.86 & 5.84 & 270 & 273 & 284 & 316.7 & 342.5 & 336 & 4.00 & 4.12 & 4.68 \\
\hline Corn oil & \pm 0.42 & \pm 0.42 & \pm 0.43 & \pm 13.7 & \pm 25.4 & \pm 16.3 & \pm 16.4 & \pm 13.5 & \pm 25.6 & \pm 0.32 & \pm 0.32 & \pm 0.50 \\
\hline
\end{tabular}

* Values are significant relative to control $(P<0.01)$

The internal relationships between the cholesterol and other lipid classes observed in the serum of different rat groups also hold true in the rat organs heart, liver and spleen but not for kidney. So, high level of deposited cholesterol were accompanied by high levels of deposited total lipid and triglycerides but low one of phospholipids. \pm Values it means standard deviation of the mean.

The data in Table IV show that the rat group receiving butter as the sole source of fat exhibited higher levels of serum enżyme activities of acid phosphatase, alkaline phosphatase, GOT and GPT at the different experimental intervals. This result might refer to an affected heart and liver function as referred by Hawcroft (21). The affected function of heart and liver 
Table III

Lipid fractions in the kidney and spleen of rats administered different fat sources.

\begin{tabular}{|c|c|c|c|c|c|c|c|c|c|c|c|c|}
\hline \multirow{3}{*}{ Treatments } & \multicolumn{3}{|c|}{$\begin{array}{l}\text { Total lipids } \\
\mathrm{gm} / 100 \mathrm{gm}\end{array}$} & \multicolumn{3}{|c|}{$\begin{array}{l}\text { Cholesterol } \\
\mathrm{mg} / 100 \mathrm{gm}\end{array}$} & \multicolumn{3}{|c|}{$\begin{array}{l}\text { Phospholipids } \\
\mathrm{mg} / 100 \mathrm{gm}\end{array}$} & \multicolumn{3}{|c|}{$\begin{array}{l}\text { Triglyceride } \\
\mathrm{gm} / 100 \mathrm{gm}\end{array}$} \\
\hline & \multicolumn{12}{|c|}{ Time in months. } \\
\hline & 2 & 3 & 4 & 2 & 3 & 4 & 2 & 3 & 4 & 2 & 3 & 4 \\
\hline Control & 7.95 & 7.85 & 8.15 & 460.8 & 468.2 & 475 & 1168 & 1146 & 1184 & 5.68 & 5.84 & 5.65 \\
\hline & \pm 0.54 & \pm 0.18 & \pm 0.74 & \pm 32.5 & \pm 30.6 & \pm 18.7 & \pm 92.5 & \pm 85.4 & \pm 92.7 & \pm 0.52 & \pm 0.46 & \pm 0.51 \\
\hline Butter & 7.85 & 7.98 & 8.23 & 462.8 & 466.8 & 472.4 & 1124 & 1135 & 1164 & 5.46 & 5.74 & 5.84 \\
\hline & \pm 0.77 & \pm 0.43 & \pm 0.56 & \pm 38.5 & \pm 36.4 & \pm 42.7 & \pm 100.4 & \pm 56.4 & \pm 72.9 & \pm 0.41 & \pm 2.6 & \pm 0.57 \\
\hline \multirow[t]{2}{*}{ Samn } & 8.10 & 8.05 & 8.12 & 466.5 & 470.5 & 468.6 & 1089 & 1156 & 1146 & 5.60 & 5.70 & 5.74 \\
\hline & \pm 0.14 & \pm 0.72 & \pm 0.15 & \pm 45.2 & \pm 31.3 & \pm 35.6 & \pm 91.6 & \pm 60.5 & \pm 70.2 & \pm 0.32 & \pm 0.48 & \pm 0.46 \\
\hline Morta & 7.96 & 8.08 & 7.96 & 467.5 & 472.5 & 476 & 1116 & 1148 & 1146 & 5.67 & 5.64 & 5.80 \\
\hline Corn oil & \pm 0 & \pm 0.28 & \pm 0.22 & \pm 28.4 & \pm 32.5 & \pm 41.5 & \pm 64.5 & \pm 102.1 & \pm 110.6 & \pm 0.46 & \pm 0.36 & \pm 0.42 \\
\hline \multirow[t]{2}{*}{ Control } & 2.64 & 2.83 & 2.96 & 154.6 & 158.4 & 184.6 & 1103 & 1068 & 1105 & 1.98 & 2.01 & 1.98 \\
\hline & \pm 0.23 & \pm 0.22 & \pm 0.14 & \pm 12.6 & \pm 11.2 & \pm 10.5 & \pm 81.4 & \pm 71.5 & \pm 64.5 & \pm 1.16 & \pm 0.20 & \pm 0.12 \\
\hline \multirow[t]{2}{*}{ Butter } & 3.05 & 3.12 & 2.98 & 165.4 & 178 & 195.4 & 1095 & 1032 & 1085 & 2.25 & 2.14 & 1.85 \\
\hline & \pm 0.31 & \pm 0.30 & \pm 0.15 & \pm 12.7 & \pm 8.6 & \pm 10.5 & \pm 102.5 & \pm 100.5 & \pm 92.7 & \pm 0.21 & \pm 0.18 & \pm 0.19 \\
\hline Samn & 2.86 & 2.64 & 2.80 & 155.6 & 165.4 & 174.5 & 1105 & 1090 & 1102 & . 1.83 & 1.56 & 1.74 \\
\hline & \pm 0.18 & \pm 0.14 & \pm 0.08 & \pm 12.5 & \pm 9.6 & \pm 9.8 & \pm 42.6 & \pm 90.5 & \pm 82.6 & \pm 0.16 & \pm 0.05 & \pm 0.16 \\
\hline Morta + & 2.68 & 2.74 & 2.90 & 150.8 & 153.4 & 180.5 & 1072 & 1089 & 1106 & 1.55 & 1.50 & 1.53 \\
\hline Corn oll & \pm 0.15 & \pm 0.19 & \pm 0.19 & \pm 15.0 & \pm 13.2 & \pm 16.5 & \pm 95.2 & \pm 100.4 & $\pm 110.6^{\circ}$ & \pm 0.12 & \pm 0.09 & \pm 0.08 \\
\hline
\end{tabular}

* Values are significant relative to control $(P<0.01)$.

might be due to the deposition of high levels of both cholesterol and total lipids in these two organs as previously observed.

It is also noticed that the butter rat group attained the highest GOT/GPT ratio which might refer to an affected heart as stated by Hawcroft (21). Although morta rat group did exhibit high levels of serum or \pm Values it means standard deviation of the mean.

organs cholesterol they seem from the serum enzyme activities to have impaired functions of both liver and heart. As morta is expected to incorporate some cholesterol oxidation products as previously concluded, it concluded that these products still exert some undesirable biological effects as stated by NouroozZadeh and Appelquist (17).

Table IV

Phosphatase and transaminase activities in the serum of rats fed different fat sources.

\begin{tabular}{|c|c|c|c|c|c|c|c|c|c|c|c|c|c|c|c|}
\hline \multirow{3}{*}{ Treatments } & \multicolumn{3}{|c|}{ Acid phosph. } & \multicolumn{3}{|c|}{ Alk. phosph. } & \multicolumn{3}{|c|}{ S.G.O.T. } & \multicolumn{3}{|c|}{ S.G.P.T. } & \multicolumn{3}{|c|}{ Got/Gpt ratio } \\
\hline & \multicolumn{15}{|c|}{ Time in months } \\
\hline & 2 & 3 & 4 & 2 & 3 & 4 & 2 & 3 & 4 & 2 & 3 & 4 & 2 & 3 & 4 \\
\hline \multirow[t]{2}{*}{ Control } & 7.32 & 7.45 & 7.26 & 26.4 & 28.4 & 28.5 & 42.6 & 40.5 & 41.6 & 21.6 & 22.6 & 20.4 & 1.97 & 1.97 & 2.04 \\
\hline & \pm 0.45 & \pm 0.62 & \pm 0.71 & $\pm 1: 92$ & \pm 2.4 & \pm 1.20 & \pm 3.5 & \pm 1.82 & \pm 1.90 & \pm 2.05 & \pm 1.35 & \pm 1.51 & \pm 0.12 & \pm 0.11 & \pm 0.08 \\
\hline \multirow[t]{2}{*}{ Butter } & 8.28 & 10.46 & 14.36 & $35.4^{*}$ & $36.7^{*}$ & $39.5^{*}$ & $62.5^{*}$ & $64.6^{*}$ & $60.7^{*}$ & $24.5^{*}$ & $25.4^{*}$ & $24.6^{*}$ & 2.55 & 2.54 & 2.47 \\
\hline & \pm 0.8 & \pm 1.0 & \pm 0.9 & \pm 3.1 & \pm 2.8 & \pm 3.2 & \pm 6.25 & \pm 4.32 & \pm 4.6 & \pm 2.10 & \pm 1.36 & \pm 1.56 & \pm 0.13 & \pm 0.15 & \pm 0.13 \\
\hline \multirow[t]{2}{*}{ Samn } & 7.35 & 8.32 & 8.24 & 32.5 & 33.6 & 34.5 & 52.4 & 52.6 & 54.4 & 23.6 & 22.6 & 22.8 & 2.22 & 2.33 & 2.38 \\
\hline & \pm 0.32 & \pm 0.32 & \pm 0.24 & \pm 3.02 & \pm 3.1 & \pm 3.2 & \pm 4.2 & \pm 3.8 & \pm 4.5 & \pm 2.11 & \pm 1.32 & \pm 1.40 & \pm 0.24 & \pm 0.21 & \pm 0.21 \\
\hline Morta + & 7.46 & 7.95 & 8.21 & 33.8 & 32.6 & 33.5 & 48.4 & 51.5 & 49.4 & 23.8 & 22.8 & 22.4 & 2.03 & 2.26 & 2.20 \\
\hline Corn oil & \pm 0.50 & \pm 0.76 & \pm 0.72 & \pm 1.7 & \pm 2.5 & \pm 3.1 & \pm 4.6 & \pm 3.7 & \pm 4.2 & \pm 2.46 & \pm 2.31 & \pm 1.62 & \pm 0.16 & \pm 0.12 & \pm 0.21 \\
\hline
\end{tabular}

\footnotetext{
* Values are significant relative to control $(P<0.01)$.
}

\pm Values it means standard deviation of the mean. 
The data in Table $V$ show the contents of serum protein fractions in rats fed different fat sources. The general view shows that most changes in these components were slight indicating that protein metabolism was not affected under conditions of different fat sources or variable levels of dietary or plasma cholesterol. Nevertheless, the butter rat group showed the relatively highest ratio of albumin/globulin at the first and second experimental intervals referring to slightly affected protein metabolism. In addition, this butter rat group exhibited the least levels of serum total protein which support the previous conclusion that protein metabolism was negatively affected. This result can be understood on the ground of an impaired liver function previously noticed.

Table $\mathrm{V}$

Serum protein fractions in rats fed different fat sources.

\begin{tabular}{|c|c|c|c|c|c|c|c|c|c|c|c|c|}
\hline \multirow{3}{*}{ Treatments } & & $\begin{array}{l}\text { Protein } \\
\text { gm/dl }\end{array}$ & * & & $\begin{array}{l}\text { Albumin } \\
\mathrm{gm} / \mathrm{dl}\end{array}$ & & & $\begin{array}{l}\text { Globulin } \\
\text { gm/d }\end{array}$ & & & $\begin{array}{l}\text { Alb/Glob } \\
\text { ratio }\end{array}$ & \\
\hline & \multicolumn{12}{|c|}{ Time in months } \\
\hline & 2 & 3 & 4 & 2 & 3 & 4 & 2 & 3 & 4 & 2 & 3 & 4 \\
\hline \multirow[t]{2}{*}{ Control } & 6.36 & 6.45 & 6.42 & 3.24 & 3.24 & 3.15 & 3.12 & 3.21 & 3.27 & 1.01 & 1.01 & 0.96 \\
\hline & \pm 0.4 & \pm 0.6 & \pm 0.4 & \pm 0.26 & \pm 0.21 & \pm 0.31 & \pm 0.30 & \pm 0.18 & \pm 0.24 & \pm 0.08 & \pm 0.07 & \pm 0.08 \\
\hline \multirow[t]{2}{*}{ Butter } & 6.10 & 6.15 & 6.26 & 3.32 & 3.26 & 3.21 & 2.78 & 2.89 & 3.05 & 1.19 & 1.13 & 1.05 \\
\hline & \pm 0.32 & \pm 0.51 & \pm 0.6 & \pm 0.40 & \pm 0.41 & \pm 0.21 & \pm 0.21 & \pm 0.24 & \pm 0.29 & \pm 0.13 & \pm 0.12 & \pm 0.10 \\
\hline \multirow[t]{2}{*}{ Samn } & 6.35 & 6.25 & 6.36 & 3.20 & 3.22 & 3.26 & 3.15 & 3.03 & 3.10 & 1.02 & 1.06 & 1.05 \\
\hline & \pm 0.21 & \pm 0.4 & \pm 0.42 & \pm 0.24 & \pm 0.32 & \pm 0.24 & \pm 0.30 & \pm 0.16 & \pm 0.30 & \pm 0.09 & \pm 0.16 & \pm 0.09 \\
\hline Morta + & 6.74 & 6.70 & 6.98 & 3.30 & 3.45 & 3.65 & 3.44 & 3.25 & 3.33 & 0.96 & 1.06 & 1.10 \\
\hline Corn oil & \pm 0.62 & \pm 0.35 & \pm 0.24 & \pm 0.32 & \pm 0.18 & \pm 0.26 & \pm 0.16 & \pm 0.21 & \pm 0.23 & \pm 0.07 & \pm 0.09 & \pm 0.11 \\
\hline
\end{tabular}

* Values are significant relative to control $(P<0.01)$.

\pm Values it means standard deviation of the mean.

Table VI.

Serum contents of glucose, creatinine and uric acid in rats fed different fat sources.

\begin{tabular}{|c|c|c|c|c|c|c|c|c|c|}
\hline \multirow{3}{*}{ Treatments } & \multicolumn{3}{|c|}{$\begin{array}{l}\text { Glucose } \\
\mathrm{mg} / \mathrm{dl}\end{array}$} & \multicolumn{3}{|c|}{$\begin{array}{c}\text { Creatinine } \\
\mathrm{mg} / \mathrm{dl}\end{array}$} & \multicolumn{3}{|c|}{$\begin{array}{l}\text { Uric acid } \\
\mathrm{mg} / \mathrm{dl}\end{array}$} \\
\hline & \multicolumn{9}{|c|}{ Time in months } \\
\hline & 2 & 3 & 4 & 2 & 3 & 4 & 2 & 3 & 4 \\
\hline \multirow[t]{2}{*}{ Control } & 96 & 102 & 106 & 0.85 & 0.86 & 0.98 & 5.46 & 5.20 & 5.08 \\
\hline & \pm 7.2 & \pm 8.5 & \pm 7.6 & \pm 0.043 & \pm 0.06 & \pm 0.08 & \pm 0.34 & \pm 0.51 & \pm 0.48 \\
\hline \multirow[t]{2}{*}{ Butter } & 112 & 120 & $126^{*}$ & 0.86 & 0.89 & 0.88 & 5.82 & 5.92 & 6.03 \\
\hline & \pm 8.2 & \pm 6.2 & \pm 5.4 & \pm 0.07 & \pm 0.09 & \pm 0.04 & \pm 0.46 & \pm 0.58 & \pm 0.32 \\
\hline \multirow[t]{2}{*}{ Samn } & 106 & 108 & 110 & 0.85 & 0.08 & 0.96 & 4.85 & $5 \sin 2$ & 5.43 \\
\hline & \pm 9.5 & \pm 6.2 & \pm 6.4 & \pm 0.07 & \pm 0.05 & \pm 0.05 & \pm 0.35 & \pm 0.32 & \pm 0.38 \\
\hline Morta + & $98^{\circ}$ & 96 & 102 & 1.1 & 1.05 & 0.98 & 5.26 & 5.3 & 5.38 \\
\hline Cornoil & \pm 6.8 & \pm 8.2 & \pm 3.5 & \pm 0.12 & \pm 0.09 & \pm 0.04 & \pm 0.52 & \pm 0.46 & \pm 0.42 \\
\hline
\end{tabular}


It is noticed in Table VI that the butter rat group showed the highest level of serum glucose while samn group showed only slight increases in this parameter. The raised rates of serum glucose might be due to the impaired function of liver which is reported to play an important role in the regulation of serum glucose. Alternatively, it may be due to the lowered circulating insulin level caused by the high level of serum glucose as indicated by Tsai (22).

The butter rat group exhibited trivial changes in the level of serum creatinine but relatively higher increases in the level of serum uric acid. This may be due to renal insufficiency caused by the high serum cholesterol level observed in this rat group. Although the morta group did not show big differences in the level of serum uric acid, it exhibited the comparatively highest creatinine level in serum referring to impaired renal function. This effect might have resulted from the oxidation products of cholesterol which are expected to aggregate in the morta fraction. The oxidation products of cholesterol were reported to have undesirable biological effects, Nourooz-Zadeh and Appelqvist (17).

\section{REFERENCES}

1. Nawar, W.W.-"Food Chemistry".-2 Ed.-O.R. Fennema.Marcel Dekker, Inc., New York and Basel, 1985.

2. Ismail, A.A., and Hamed, N.S.-"Cholesterol content in buffalo milk and its distribution in some dairy products".-Egypt. J. Dairy Sci. 6 (1978) 91-94.

3. Hassan, M.N.A.; Rady, A.H., and Ibrahim, M.K.-"Stability and keeping quality of butter oil and samn".-Grasas y Aceites 40 (1989) 6-9.

4. Campbell, J.A.-"Methodology of protein evaluation".-P.A.G. Nut. Document R 101 Add. 37 June Meeting New York, 1961.

5. Knight, J.A.; Anderson, S., and Rawie, J.M.-"Chemical basis of sulphophosphovanillin reaction for estimating total serum lipid".-Clin. Chem. 18 (3) (1972) 199-204.

6. Chaurchami, A.J.; Iler, W.A., and Stein, I.B.-"Determination of total and free cholesterol".-Clin. Chem. 5 (1959) 609612.
7. Fletcher, M.T.-“A colorimetric method for estimating serum triglycerides".-J. Clin. Chem. Acta 22 (1968) 393-397.

8. Bartlett, G.R.-"Colorimetric assay methods for free and phosphorylated glyceric acids".-J. Biol. Chem. 234 (1969) 71.

9. Reitman, S., and Frankel, S.-"A colorimetric method for the determination of serum oxaloacetic and glutamic pyruvic transaminasen.-Amer. J. Clin. Path. 28 (1957) 56.

10. Belfield, A., and Goldberg, D.M.-"Determination of alkaline phosphatase and acid phosphatase".-Enzymes 12 (1971) 561.

11. Lowry, O.H.; Rosebronght, N.I.; Farr, A.L., and Randoll, R.J.-"Protein measurement with the folin phenol reagent".-J. Biochem. 193 (1951) 265.

12. Caraway, W.T.-“Determination of serum uric acid".-Std. Method. Clin. Chem. 4 (1963) 239.

13. Chasson, A.L.; Gardy, H.J., and Stenley, M.A.-"Determination of serum creatininen.-Amer. J. Clin Path. 35 (1961) 83.

14. Snedecor, G.W., and Cochran, W.G.-"Statistical methods".(6th edn).-lowa State Univ. Press., Ames. lowa, USA, 393 pp., 1967.

15. Tietz, N.W.-"Fundamentals of clinical Chemistry".-W.B. Saunders, Phila, 1970.

16. Simith, L.L.-"Cholesterol autoxidation".-Plenum Press., New York and London, 1981.

17. Nourooz-Zadeh, J., and Applegvist, L.J.-"Cholesterol oxides in Swedish foods and food ingredients".-J. Food Sci. 52 (1987) 57-62.

18. Park, S.W., and Addis, P.B.-"Cholesterol oxidation products in some muscle foods".-J. Food Sci. 52 (1987) 1500-1503.

19. Mohamed, A.I.-"Comparative biochemical study on cholesterol methabolism, cholesterol balance and hypercholesterolemic animals".-M. Sc. Thesis. Dept. of Biochem., Fac. of Agric. Cairo. Univ., 1977.

20. Abdel-Samad, A.; Abdel-Rahim, E.A., and Ashoush, Y.A."Cholesterol metabolism in hypercholesterolemic animals".-Bull. Fac. of Agric., Cairo Univ. 36 (1985) 234271.

21. Hawcroft, D.-“Diagnositic enzymology".-John Wiley and Sons, New York, 1978.

22. Tsai, A.C.-"Serum insulin concentration, insulin release and degradation, glucose tolerance and in vivo, insulin sensitivity in cholesterol-fed rats ${ }^{n} .-\mathrm{J}$. Nutr. 107 (1977) 546-551.

(Recibido: Septiembre 1990) 